to deterioration at a rato almost unknown in temperate latitudes. A singlo rainy season can com. pletely destroy the fertility of a tropical soil unwisely oxposed.

\section{Soil Destruction in Malaya}

Tre damage done to agricultural land by various forms of mining is considered by Sir Lewis $\mathrm{L}$. Fermor in his exhaustive "Report upon the Mining Industry of Malaya" (Kuala Lumpor : Gov. Press, 1939. 6s.). Tho destruction of land by the stacking of waste rock and gangue is small becauso the provalent forms of tinmining result in floods of water, heavily charged with silt, either as coarse as sand or as fine as mud. This silt, carried by tho offluent water, chokes streams and causes flooding to such an extent that siltretention schemes, necessitating dams or woirs, aro obligatory. But much damago las been done in the past, and somo is still being done, especially in tho mining process of destroying hillside by water under hydraulic pressure. Again, the romoval of the top layers of soil and their mixing with lower layors, which is unavoidablo in the process known as dredging, render the wholo surface within a mining concession unfertile by tho timo tho land is returned to agricultural use. Against theso objections to mining must bo placed the fertilizing value on flooded land of a thin deposit of silt. The writer is insistent that rubber cultivation is equally harmful, in fact moro so, in ruining land by encouraging soil erosion and leading to the removal of fertile surface layers. Clean weeding, a fetish of the rubber planter, causes soil removal between tho rows of trees, and can bo provented only by the wise use of cover crops. Sir Lewis estimates that rubber cultivation has caused the addition of $33,000,000$ tons of silt to the river systems sinco 1905, whilo tin-mining has contributed only $16,000,000$ tons. The debris from the rubber lands is both coarso and fine, and does more harm than the fine silt from the mines, somo of which is carried to sea, and some of which fertilizes the land.

\section{Newton's Letters}

Is Osiris (7, 523-555; 1939) Mr. Jean Polsencer, whoso interest in the subject is woll known, has reproduced somo nino lotters from Nowton's unpublished correspondenco. Four documents aro shom in reduced facsimile, and all are accompanied by explanatory notes. The first four letters, between Newton and Oldenburg, are taken from tho Portsmouth Collection in the University Library, Cambridgo. Tho next two, botween Nowton and Hooke, are in tho Iibrary of tho Historical Society of Penn. sylvania at Philadelphia. Of all theso the main thomo is optical. Two other lotters betreen Newton and Hooke come from the Pierpont Morgan Library in Now York; their subject-matter is of very minor interest. For tho period covered by these eight lotters (1672-78) little original material bearing on Newton's lifo has been published. The ninth document is a joint report signed by Newton and Halley on the performance of a magnetic needle. This is an official paper dated 1712, and preserved in the Public Record
Office. It is two years sinco Mr. Pelseneer, writing in Ciel et Terre, pointed out with a referenco to Stukeley's Memoirs of Sir Isaac Nowton's Lifo, edited by A. H. Whito and then lately published, that the story of Newton and the applo certainly did not originato in tho fertile imagination of Voltaire.

\section{Early History of Antarctic Exploration}

Tne criticisms levelled by Prof. Wr. H. Hobbs at certain English explorers of West Antarctica of the early part of last century (Trans. Amer. Phil. Soc., 31, Part 1, Jan. 1939) were discussed in Nature of April 29, 1939, p. 731. A much fuller and a most scholarly treatment by MIr. A. R. Hinlis of Prof. Hobbs's strictures appears in tho Geographical Joumal of October under the heading "On Somo Misropresentations of Antarctic History". The titlo indicates the naturo of tho conclusions which Mr. Hinlss reaches. From a study of relovant documents, including original maps, ho shows conclusively that Prof. Hobbs's claim that Palmer and not Bransfield discovered the Antarctic continent is falso and that thero is no foundation for Prof. Hobbs's contention that the chart signed by Bransfield which is in the Hydrographic Offico is not genuine, and that Prof. Hobbs has no justification for discarding tho account of Bransfield's voyage which appeared in the Literary Gazette (vol. 5, November 1821). No argument that Prof. Hobbs brings to this discussion can shake the authenticity of the documents on which Bransfield's claim to the discovery of Trinity Iand, the first sighting of tho Antarctic continent, is founded. Mr. Hinks raises many other points in his articles, including Prof. Hobbs's aspersions on the good faith of $\mathrm{J}$. Weddell, whoso discoveries conclusively stand the test of any inquiry and criticism. The article may bo accepted as a final reasoned answer to tho attacks mado by Prof. Hobbs on these English navigators of Antarctic seas.

\section{Germany's Oil Supplies}

IN a carefully reasoned articlo published in the November issue of the Industrial Chemist, Dr. A. J. V. Underwood explains why in his opinion it is unlikely that Germany's belligerent activities will bo suspended owing to shortage of oil. The present rato of production of oil and alternativo fuels in tho German Reich is estimated as $4,300,000$ tons. This figure includes potential production of plants expected to be in operation by the end of this year. If plants which are likely to bo in production by the end of 1940 or beginning of 1941 are included in tho estimate, the potential rato of production of oil from all sources becomes $6,550,000$ tons per year. In addition. imports of oil are at present available to Germany from Estonia, Rumania and the U.S.S.R. Theso with home-produced oil bring her total resources to $7,000,000$ tons a year. If home production is increased as is anticipated, Germany will have access to $9,300,000$ tons of oil a year. In 1938 Germany, including Czechoslovakia, consumed 7,900,000 tons of oil. This is substantiallyless than the $9,300,000$ tons per annum poten. 
tially available, but has reference to peace-time conditions. In war-time, consumption by the fighting services will obviously increase even beyond the figure for 1938 when Germany was mobilizing, but at the same time civilian consumption will drop on account of the stringent rationing schemes now in force; also less oil will be used by Germany's mercantile marine, the activities of which have been so severely restricted of late. It is probable, therefore, that Germany's potential resources of oil will be sufficient for her war-time needs, and as reserves are available to supplement home production until such time as all projected plants are in operation, it is unlikely that she will go short of oil, unless through drastic changes in the international situation.

\section{Folsom Man: Further Investigation in Colorado}

A Funtrien season of excavation on the Lindenmeier site in northern Colorado has again failed to produce any trace of skeletal remains of Folsom man. Until such ovidence is forthcoming, and on the assumption that it will afford some certain indication of the relation of the authors of the culture to the Amerindian peoples, the Folsom industry, with its distinctive characteristics, hangs in tho air. The geological interpretation of the Folsom deposits on the Lindenmeier site assigns them to the last phase of the glacial period at an approximate dating of 12,000-25,000 years ago, and an association with an extinct fauna including mammoth, camel and oxtinct forms of bison. In the courso of excavations carried out by Dr. F. H. H. Roborts, jun., in the past summer, the fifth season of his investigations on the site, it is reported in a statement issued by the Smithsonian Institution of Washington, that among animal bones, which had been chopped and split by man, was found the skull of an extinct bison measuring 36 inches between the tips of the horn cores-fully a foot wider than the spread between the horns in the modern species. In four months' work Dr. Roberts opened up a new section of the site over an area of some $45 \mathrm{ft}$. by $60 \mathrm{ft}$. to an average depth of six feet. His finds, in addition to the characteristic projectile points and previously lnown artefacts, included new forms of knives and scrapers, two to three times as large as those found before. A new feature in the culture is the bone bead, not hitherto found in Folsom deposits. Of those found here, one shows definite ornamentation in the form of $a$ simple geometric design scratched on the surface.

\section{Mental Hygiene in Old Age}

IN a paper on this subject read before the Section on Care of the Aged, Welfare Council, New York City (Mental Health, 23, 257; 1939), Dr. George Lawton, psychological adviser to the Andrew Freedman Home, New York City, maintains that there is no group of persons whose mental welfare is more neglected than that of old people. This indifference, he declares, is world-wide even in countries with advanced social services. Although there has been for many years a guidance clinic for the aged in San
Francisco, no definito steps have been taken for establishing a similar one in Now York. Dr. Lawton asserts that what little knowledge we have of old people is based on pathological material, while we possess very littlo information about non-psychotic old persons. Ho suggests that the psychological difficulties presented by aged peoplo should be clissified as follows: (I) the problems of nourotic, borderline psychotic, psychotic, feeble-minded, and deterioriated individuals; (2) the minor mal-adjustments of fairly adequato old peoplo caused by excessive economic pressures and inhibitory social attitudes; (3) the stresses and strains of persons undergoing normal mental and emotional decline. According to Dr. Irawton, the management of the problem of senescence should include the following measures, among others: (1) intensive, systematic studies over long periods of time, of the mental abilities, interests, recreations, emotions and personalities of larger groups of men and women in town and country in each decado from forty to sixty, (2) when such facts have been collected, guidance clinics should bo set up to function in a similar manner to child guidance clinics; (3) courses in geriatries should bo established in the medical schools to give future physicians a better understanding of tho effects of mental attitudes on the bodily ailments of tho aged.

\section{Wild-life Restoration in the United States}

IN tho United States, as in other progressive countries, the existence of many wild creatures has been threatened by the appropriation of lands for farming and industrial purposes, the destruction of living places and breeding places, and tho gradual disappearance of natural food and cover. To check this decrease of wild-life, the Foderal Government passed two years ago ono of the most beneficial measures of recent years, tho Federal Aid to IVild. life Restoration Act, briefly known as the Pittman. Robertson Act of 1937. The co-operative scheme which it envisages is one that might well be adopted in other countries, and a summary of its provisions and explanation of the co-operation which it secks are now given by Albert M. Day (U.S. Dept. Agric. Misc. Pub. No. 350 ; 1939). The Act recognizes the fundamental principlo that wild-life is linked with tho land, and aims at tho restoration of suitable environment in which wild birds and mammals may live and multiply. 'The Federal Government is willing to contribute materially towards this restoration programme, since it is known that individual States have been unable to cope with the situation because of lack of funds. But a State to qualify for a sharo of the grant-up to 75 per cent of the cost of work performed on approved projects-must have passed laws for the conservation of wild-life, which shall include a prohibition against diverting fees paid by hunters to any other purpose than the administration of the State fish and gamo department. Already the Act appears to bo working effectively. The grand total allocated for conservation projects in 1939 was 1;186,666 dollars, of which State legislatures 